\title{
Effect of Leadership and Achievement Motivation on Teacher Performance
}

\author{
Yusdi Andra \\ Universitas Jambi \\ Jambi, Indonesia \\ yusdiandra@yahoo.com
}

\author{
Siti Syuhada \\ Universitas Jambi \\ Jambi, Indonesia
}

\begin{abstract}
Implementation of this research is to know the influence of leadership on teacher performance and achievement motivation to the performance of teachers Jambi City. This research uses survey method with the causal approach. The in place of this research is Senior High School (SMA) in the city of Jambi as many as 12 schools with the number of civil servant teachers and teachers Honor 708. Data collection using: Instrument is a questionnaire. A testing technique uses Pearson Product Moment, and then the calculation of reliability uses Alpha Cronbach formula. This research produces; first, there is a leadership influence on teacher performance; secondly, there is the influence of achievement motivation on teacher performance of SMA in Jambi City. The implication of this research is the improvement of teacher performance can be done through the improvement of leadership and achievement motivation.
\end{abstract}

Keywords-Teacher performance, leadership, achievement motivation

\section{INTRODUCTION}

Law No. 20 of 2003, on the National Education System article 3 states that national education functions to develop the ability and form the character and civilization of a dignified nation in order to educate the nation's life, aims for the development of potential learners to become human beings who believe and piety to God the One and Only, has a noble character, is healthy, knowledgeable, capable, creative, independent, and becomes a democratic and responsible citizen [1].

Education is a very important aspect to build the civilization of the nation, especially Indonesia. With a population of more than 230 million, if not supported by a strong educational base, then the large population will only be a burden rather than a basic capital of development.

A very important container to support the achievement of educational goals is the school. School is an organization consisting of elements of principals, teachers, students, administrative staff, facilities and school infrastructure. The principal is an important component responsible for the implementation of education in schools. As the headmaster of the school functions to combine elements that exist in the school, so it can be well-coordinated educational goals in accordance with targets and plan that have been made [2].
In the implementation of the principal's education as a leader in school is crucial in improving the quality of human resources, especially educational personnel. The leadership of the principal is expected to improve the performance of teachers in carrying out teaching and learning activities (KBM), thus will also affect the quality of learning outcomes. Student learning outcomes are strongly influenced by the teaching and learning process (PBM) of teachers because teachers play an important role in the success of learners. The quality of education is closely related to the performance of teachers, especially in learning.

Law number 14 of 2005, on teachers and lecturers, chapter IV Chapter 8 confirms that teachers are required to have academic qualifications, competencies, educator certificates, physical and spiritual health, and have the ability to realize national education objectives. Further Article 9 describes the academic qualifications referred to in Article 8 obtained through higher education or undergraduate diploma program. Article 10 paragraph (1) referred to in article 8 covers pedagogic competence, personality competence, social competence, and professional competence obtained through professional education [3].

There are three types of skills that teachers must master are as follows: (1) technical skills (technical skills), the skills to use methods and techniques of teacher development, (2) managerial skills, i.e. Skill in decision-making in relation to the institutional elements of a coach. (3) Human skills, namely the skills to cooperate with teachers and other school apparatus in order to carry out their work effectively.

The three types of skills according to Alfonso's assumptions are very important. Three skills are essential abilities that can be made by the leadership to respond to the areas of duty. Not only had that Alfonso more firmly said that the three types of skills are a competence that determines the performance success of a coach.

The term performance has a reason when it is associated with the notion of performance as an understanding that is constantly evolving. Performance, in this case, is something that shows on the work or performance of a person in performing tasks in accordance with the responsibilities given.

Performance is an evaluation of the results of a person's behavior." Performance is the work of a person's work skills 
that can be seen from the completion of a job [4]. Performance is defined as the task accomplishment, which is the completion of the work of the work of a job done well [5].

Performance, in this case, is something that shows on the work or performance of a person in performing tasks in accordance with the responsibilities given. Task refers to goaldirected behaviors under the individual's control that support organizational objectives". Performance is guided by hints of behavior under a person's control to support the organization's goals.

Based on the above description can be concluded that the performance of teachers is the performance achieved by teachers in carrying out the main task and function effectively and efficiently in accordance with the responsibilities given to him to achieve organizational goals that have been set.

Achievement motivation as the concept we use when we describe the forces acting on or within an individual to initiate and direct behavior. Achievement motivation is defined as a concept we use when we describe actions within a person to initiate and direct behavior. The above definition describes the differences of an intensity of behavior and also indicates the direction of a behavior [6].

Achievement motivation provides an opportunity for organizations and individuals to perform positively with regard to the effectiveness of performance. Gibson et al believe that motivational theories can be grouped into two categories: content theories and process theories. The content theory focuses on the factors that exist within an employee, in which factors are the factors that drive, direct, maintain and stop the behavior, or as factors that determine the specific needs that can motivate employees. While process theories describe and analyze how the behavior is driven, directed, guarded and stopped by the main external factors of a person. Furthermore, it is said that achievement motivation refers to employee's behavior in improving performance to the organization [7].

Dirrection or motivation is the essence, it is a skill in aligning employee and simultaneously with attainment or organizational objectives. Motivation is an expertise in directing employees and organizations to work successfully so that the desire of employees and organizational goals as well as achieved [7].

Motivation involves a psychological process to reach the peak of an individual's desire and intention to behave in a certain way. Achievement motivation as "a power within a person impacting the directions, the intensity, and persistence of his behavior." A person who is motivated, willing to try to use a special level of effort (intensity), for a certain time (persistence), and toward a particular destination (direction) [8].

Motivation that is a willingness to do a higher level toward the goals of the organization, conditioned by the ability of a business needed to achieve satisfaction. Willingness to act reflects something that can be seen. The outcomes of achievement motivation are generally assessed by the behaviors shown, the amount of effort spent, or the preferred strategy used to complete a job or task. The real effort is the result of achievement motivation related to doing direct [9].

Based on the description above can be concluded that the motivation of achievement is the impetus in a person to excel in carrying out tasks that caused by factors from within and from outside in a person to achieve better performance in achieving organizational goals.

Leadership is to stimulate people in the organization to perform high. Leadership involves motivating and communicating with workers, both individually and in groups. The characteristic of Bateman and Snell's opinion makes it clear that leadership is to stimulate people in the organization to perform high, including motivating and communicating with workers. Determining job responsibilities, grouping jobs into work units, compiling and allocating resources and creating conditions that enable people to work together to achieve organizational success [10].

Leadership a process of influencing a group to achieve the goal". Leadership is the process of influencing groups to achieve goals. The influence of leadership in Robbins and Coulter is based on one's ability to make changes to attitudes and behaviors of individuals or groups to achieve goals within the organization [9]. A similar opinion was also expressed by Leadership is a function of a system. When the system is change, the demands are also changed. Leadership becomes the guarantee process that an organization or a society will adapt to new economic and technological environments. Michael Maccoby concludes that the context determines the form of leadership [11].

Based on the above description collected from some writings of experts can be concluded that leadership is the use of influence between leaders and followers in contributing to achieving organizational goals.

\section{METHODS}

This research use survey method through a questionnaire to respondent which become research target. Target population that serves as the target of this research is a teacher of SMA in Jambi City. Population is a teacher of SMA in Jambi City who has become a teacher at least 2 (years) year.

This study uses Path Analysis Method, data collection techniques using the instrument in the form of questionnaires developed based on the conceptual definition, operational definition and the grid on each research variable. Data analysis procedure in the form of questionnaires used to obtain research data; leadership and achievement motivation on the performance of the teacher of SMA in Jambi City. Analysis of test requirements indicates that the score of each research variable has met the requirements for more statistical testing. Hypothesis testing is done by calculating the path coefficient Py1, Py2. Line coefficient calculation is done by using SPSS software.

\section{RESUlT AND DisCUSSION}

Before the first analysis is done the descriptive analysis. Descriptive analysis is intended to describe the description of the variables measured in this study which include: 1. Leadership Variables, 2. Achievement Motivation Variables, and 3. Teacher Performance Variables SMA Jambi. 
Some descriptive statistics include measures of central tendency or centralization of data and dissemination of data. Data centering measures include the mean value of the count, mode, and median. While the size of the data spread includes the range of data and standard deviation. The presentation of group distribution tables is presented to explain the description of research variables.

The variables measured in this study consisted of endogenous variables and exogenous variables. Endogenous variable is the variable whose value is determined in the system under study in accordance with the theoretical model in the study. Endogenous variables in this study are Teacher Performance (Y), whereas exogenous variables are variables whose values are not specified inside but outside the system under study. These exogenous variables determine the value of endogenous variables. Exogenous variables in this study include Leadership (X1), and Achievement Motivation (X2). Both of these exogenous variables can determine the Teacher Performance variable (Y). Description of statistics started from the variable Performance Teacher (Y) and then continued Variable Leadership (X1), and achievement Motivation variables (X2).

\section{A. Description of Data on Teacher Performance}

Teacher performance variable measured by 34 points statements, theoretically this variable has a score range between 34 to 170 and empirically has a score range of 89 with the lowest score 81 and the highest score 170 . Based on the data analysis can be found, the average score of 126,36, standard deviation 21,318 , median 126,00 , mode 113 , number of class 9, and length of class 9. Based on the result of calculation, criteria are made about teacher performance level with trend distribution as follows:

TABLE 1. TEACHER PERFORMANCE LEVEL

\begin{tabular}{|l|l|l|l|l|}
\hline No & Class Interval & $\begin{array}{l}\text { Middle } \\
\text { Value }\end{array}$ & Frequently & $\begin{array}{l}\text { Percentage } \\
(\%)\end{array}$ \\
\hline 1. & $81-90$ & 85,50 & 11 & 4,31 \\
\hline 2. & $91-100$ & 95,50 & 20 & 7,84 \\
\hline 3. & $101-110$ & 105,50 & 31 & 12,16 \\
\hline 4. & $111-120$ & 115,50 & 44 & 17,25 \\
\hline 5. & $121-130$ & 125,50 & 32 & 12,55 \\
\hline 6. & $131-140$ & 135,50 & 48 & 18,82 \\
\hline 7. & $141-150$ & 145,50 & 35 & 13,73 \\
\hline 8. & $151-160$ & 155,50 & 18 & 7,06 \\
\hline 9. & $161-170$ & 165,50 & 16 & 6,27 \\
\hline & Total & & 255 & 100 \\
\hline
\end{tabular}

From the above table, it is reflected that the lowest frequency of $4.31 \%$ of respondents has teacher performance that is at the interval score of $81-90$, the highest relative frequency of $18.82 \%$ of respondents have performance is in the interval score of 131-140.

\section{B. Description of data on Achievement Motivation}

The achievement motivation variable was measured by 34 points statements with 255 respondents. Theoretically, this variable has a score range of 34 to 170 and empirically has a score range of 89 ; with the lowest score 81 and the highest score 170 . Based on the results of data analysis found that the average score of 126.07, the standard deviation of 20.901, median 126, 00, mode 139, the number of class 9 and length of class 9 .

TABLE 2. Distribution OF ACHIEVEMENT Motivation TRENDS

\begin{tabular}{|c|c|c|c|c|}
\hline NO & $\begin{array}{l}\text { Class } \\
\text { Interval }\end{array}$ & $\begin{array}{l}\text { Middle } \\
\text { Value }\end{array}$ & Frequently & Percentage (\%) \\
\hline 1. & $81-90$ & 85,50 & 9 & 3,53 \\
\hline 2. & $91-100$ & 95,50 & 21 & 8,24 \\
\hline 3. & $101-110$ & 105,50 & 35 & 13,73 \\
\hline 4. & $111-120$ & 115,50 & 41 & 16,08 \\
\hline 5. & $121-130$ & 125,50 & 34 & 13,33 \\
\hline 6. & $131-140$ & 135,50 & 51 & 20,00 \\
\hline 7. & $141-150$ & 145,50 & 31 & 12,16 \\
\hline 8. & $151-160$ & 155,50 & 19 & 5,45 \\
\hline 9. & $161-170$ & 165,50 & 14 & 100 \\
\hline & Total & & 255 & \\
\hline
\end{tabular}

From the table above reflected that the lowest frequency of $3.53 \%$ of respondents, achievement motivation that is at the interval score of $81-90$, the highest relative frequency of $20.00 \%$ of respondents, achievement motivation is at the interval score of 131-140.

\section{Data Description of Leadership}

Leadership variables were measured through 38-point statements with 255 respondents. Theoretically, this variable has a range of scores between 38 and 175 and empirically the score range of 89 ; with the lowest score 93 and the highest score 182 . Based on the data analysis found that the average score of 144.50, the standard deviation of 20.685, median 147 , 00 , mode 142, number of class 9 and length of class 10. Based on the result of the calculation, criteria of leadership level are made with the following trend distribution.

TABLE 3. DISTRIBUTION OF LEADERSHIP TRENDS

\begin{tabular}{|c|c|c|c|c|}
\hline No & $\begin{array}{l}\text { Class } \\
\text { Interval }\end{array}$ & $\begin{array}{l}\text { Middle } \\
\text { Value }\end{array}$ & Frequently & Percentage (\%) \\
\hline 1. & $93-102$ & 97.50 & 7 & 2.75 \\
\hline 2. & $103-112$ & 107.50 & 11 & 4.31 \\
\hline 3. & $113-122$ & 117.50 & 27 & 10.59 \\
\hline 4. & $123-132$ & 127.50 & 30 & 11.76 \\
\hline 5. & $133-142$ & 137.50 & 37 & 14,51 \\
\hline 6. & $143-152$ & 147.50 & 44 & 17,25 \\
\hline 7. & $153-162$ & 157.50 & 46 & 18.04 \\
\hline 8. & $163-172$ & 167.50 & 27 & 10.59 \\
\hline 9. & $173-182$ & 177.50 & 26 & 10.20 \\
\hline & Total & & 255 & 100 \\
\hline
\end{tabular}

From the table above, it shows that the lowest frequency is $2.75 \%$ of respondents, the leadership is in the 93-102 score interval, the highest relative frequency is $18.04 \%$ respondent, the leadership is at the interval score of 153-162.

There are certain statistical tests that must be met for path analysis. Therefore, before performing data analysis is by using path analysis, firstly done some statistical test which is a requirement for path analysis.

\section{Test of Estimated Error Normality}

Normality testing aims to test the assumption that the sample distribution of the population is normally distributed. Normality testing techniques used in this study is Lilliefors Test. The statistical hypothesis in this normality test is: 
Ho: The estimated population error data is normally distributed

H1: the estimated population data error is not normally distributed

The provision of this test is if the statistic Account (L0) LLtable $(\alpha=0.05)$ then the data is normally distributed. Conversely, if Lcount (L0) $>$ Ltabel $(\alpha=0.05)$ then the data is not normally distributed.

1) Test Normality Data Score Master's Performance Measures on Leadership (Y over X1)

The results of Lilliefors statistical calculations, as shown in table 4 , obtained the highest $\mathrm{L} 0$ or $\mathrm{L}=0.0534$. This value is smaller than Ltabel $(n=225 ; \alpha=0.05)=0.0555$. Thus, it can be argued that the distribution of Master's Performance (Y) performance estimates of Leadership (X1) comes from a population that has a normal distribution.

2) Test of Normality Data Score of Teacher Performance on Achievement Motivation (Y over X2)

The result of Lilliefors statistic calculation, as shown in table 4, obtained the highest $\mathrm{L} 0$ or $\mathrm{L}$ count $=0.0522$. This value is smaller than Ltabel $(\mathrm{n}=225 ; \alpha=0.05)=0.0555$. Thus, it can be argued that the distribution of the Teacher
Performance (Y) performance estimate of Achievement Motivation (X2) comes from a population that has a normal distribution.

TABLE 4. SUMMARY OF NORMALITY TEST ANALYSIS $(\mathrm{N}=255)$

\begin{tabular}{|c|c|c|c|c|c|}
\hline No & Variable & $\boldsymbol{N}$ & $\boldsymbol{L}_{\text {hitung }}$ & $\mathbf{L}_{\text {tabel }}$ & Description \\
\hline 1 & Y forward $\mathrm{X}_{1}$ & 255 & 0,0534 & 0,0555 & Normal \\
2 & Y forward $\mathrm{X}_{2}$ & 255 & 0,0522 & 0,0555 & Normal \\
\hline
\end{tabular}

Description: $\alpha=(0.05)$

\section{E. Linearity Test and Significance of Regression Coefficients}

Linearity test is intended to find out how big the research data viewed from the regression line relationship between independent variables with the dependent variable. Linearity test uses F test.

1) Leadership (X1) on Teacher Performance ( $Y)$

After calculation and analysis of leadership regression equation $(\mathrm{X} 1)$ on teacher performance $(\mathrm{Y})$ is known regression equation $\mathrm{Y}=47.258+0.612 \mathrm{X} 1$. From the calculation results obtained values as presented in table 5 below:

TABLE 5. ANAVA LIST FOR MEANING AND LINEARITY X1 AND Y WITH COEFFICIENTS (A) REGRESSION EQUATION Y = 47.258 + 0.612X1

\begin{tabular}{|c|c|c|c|c|c|c|}
\hline \multirow{2}{*}{ Anava Analysis } & \multirow{2}{*}{ db } & \multirow{2}{*}{ JK } & \multirow{2}{*}{ RJK } & \multirow[t]{2}{*}{$\mathbf{F}_{\text {count }}$} & \multicolumn{2}{|c|}{$F_{\text {table }}$} \\
\hline & & & & & $\alpha=0,05$ & $\alpha=0,01$ \\
\hline Total (T) & 255 & $4,164,127$ & - & - & - & - \\
\hline $\begin{array}{l}\text { Regression (a) } \\
\text { Regression b/a) } \\
\text { Residual }\end{array}$ & $\begin{array}{l}1 \\
1 \\
253 \\
\end{array}$ & $\begin{array}{l}4,053,169.42 \\
28,358.86 \\
82,598.75 \\
\end{array}$ & $\begin{array}{l}- \\
2,8358.86 \\
326.48 \\
\end{array}$ & $89.122 * *$ & 6.74 & 3.88 \\
\hline $\begin{array}{l}\text { Match } \\
\text { Error }\end{array}$ & $\begin{array}{l}78 \\
175\end{array}$ & $\begin{array}{l}23,660.81 \\
58,937.91\end{array}$ & $\begin{array}{l}303.344 \\
336.788\end{array}$ & $0.902^{\mathrm{ns}}$ & 1.55 & 1.36 \\
\hline
\end{tabular}

From the above calculation results obtained Fcount $=$ 89.122, while at $\alpha=0.05$ Ftable $=6.74$ and $\alpha=0.01$ Ftable $=$ 3.88. Because Fcount> Ftable then the regression is very significant. In the linearity test of simple linear regression equation, the calculation results show the value Fcount $=$ 0.902 and Ftable $=1.55$ at $\alpha=0.05$, and 1.36 at $\alpha=0.01$. Because Fcount <Ftable then the model of leadership regression equation $(\mathrm{X} 1)$ on teacher performance $(\mathrm{Y})$ is linear and significant.

2) Achievement Motivation (X2) for Teacher Performance (Y)

After calculation and analysis of regression equation of achievement motivation (X2) on teacher performance (Y) is known regression equation $\mathrm{Y}=54.818+0.567 \mathrm{X} 2$. From the calculation results obtained values as presented in Table 6 below:

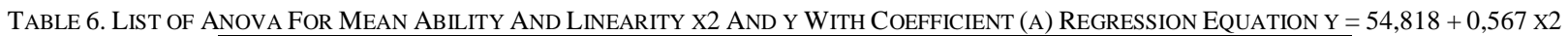

\begin{tabular}{|c|c|c|c|c|c|c|}
\hline \multirow{2}{*}{$\begin{array}{c}\text { Anava } \\
\text { Analysis }\end{array}$} & \multirow{2}{*}{ db } & \multirow{2}{*}{ JK } & \multirow{2}{*}{ RJK } & \multirow[t]{2}{*}{$F_{\text {count }}$} & \multicolumn{2}{|l|}{$F_{\text {table }}$} \\
\hline & & & & & $\alpha=0,05$ & $\alpha=\mathbf{0 , 0 1}$ \\
\hline Total (T) & 255 & $4,187,285$ & - & - & - & - \\
\hline Regression (a) & 1 & $4,071,849.92$ & - & - & & \\
\hline Regression b/a) & 1 & $35,734.18$ & $35,734.18$ & $113.433^{* *}$ & 6.74 & 3.88 \\
\hline Residual & 253 & $79,700.91$ & 315.02 & & & \\
\hline $\begin{array}{l}\text { Match } \\
\text { Frror }\end{array}$ & $\begin{array}{l}78 \\
175\end{array}$ & $\begin{array}{l}29,616.46 \\
5008444\end{array}$ & $\begin{array}{l}379.698 \\
286197\end{array}$ & $1.327^{\mathrm{ns}}$ & 1.55 & 1.36 \\
\hline
\end{tabular}

Information:

$* *$ : very significant regression $($ Fcount $=113.433>$ Ftable $=6.74)$

ns: linear regression $($ Fcount $=1,327<$ Ftable $=1.55)$ 
From the above calculation results obtained Fcount $=$ 113.433, while at $\alpha=0.05$ Ftable $=6.74$ and $\alpha=0.01$ Ftabel $=$ 3.88. Because Fcount> Ftable then the regression is very significant. In the linearity test of simple linear regression equation, the calculation results show the value Fcount $=$ 1.327 and Ftabel $=1.55$ at $\alpha=0.05$, and 1.36 at $\alpha=0.01$. Because Fhitung < Ftabel then model of achievement motivation regression equation (X2) on teacher performance $(\mathrm{Y})$ is linear and significant.

Based on the calculation of path analysis about the influence of leadership, and motivation preparation on the performance of teachers SMA Jambi City can be proved that the research hypothesis is significant at the level of $\alpha=0.05$. There is the influence of each exogenous variable to endogenous variable.

\section{F. Leadership in Teacher Performance}

The results of the first hypothesis testing showed that, leadership influence on teacher performance. The findings of the research conducted at SMA Jambi City emphasized the importance of strong leadership in an institution, both at the Provincial Education Office level, principals, subject teachers, strong leadership reflected in the fulfillment and in compliance with the process of teaching and learning activities). The facts found that there are still teachers who teach difficulties implementing RPP and KTSP and excess teaching hours that do not get a reward from the government.

Leadership is crucial to understanding how people are able to influence in organizations, powers that involve the capacity of a party to influence others [12]. In the context of teacher performance SMA in Jambi City, it is expected that leaders can influence teachers, in this case, a positive influence to develop optimally.

\section{G. Motivation to Teachers Performance}

The result of the second hypothesis testing shows that the motivation of pace has a direct effect on the performance of the teacher. Findings from research conducted on the teacher of SMA in Jambi City confirm the importance of motivation from each teacher to have the achievement.

An increase in the position of teachers will never happen without the teacher's efforts to make scientific work of PTK results, to implement KBM proportionally and professionally. To be a professional, it takes lifelong learning as defined in the Teachers and Lecturers Act. Everyone tends to develop four specific patterns of motivation as a result of his interaction with the social and cultural environment in which he lives [13]. In the life of the teacher, the dominant social environment is the school of work. Conductive environment will trigger it to compete competitively with other teachers. This healthy competition becomes part of a person to motivate himself to further develop.

Humans have a need for achievement (n, Ach), the need for affiliation n, Aff), need for power (n.Pow) These three needs can be met by the teacher, only if the teacher has the widest opportunity given by the leader in the educational institution The opportunity is not just time, what is needed is the assignment of the leadership, trust, rewards and facilities needed for the performance of the task [13].

\section{CONCLUSION}

Based on the description above and discussion of research results, then the conclusion in this study put forward as follows: (1) achievement motivation effect on the performance of teachers SMA Jambi City. This means that if the motivation of achievement of high teachers, then the performance of SMA of Jambi City teachers will experience improvement, (2) leadership affect the performance of teachers SMA in Jambi City. This means that the high performance of teachers of SMA Jambi City is influenced by the leadership. If leadership is effective, then the performance of high school teacher Jambi City will be high.

\section{REFERENCES}

[1] Law No. 20 of 2003, on the National Education System, 2003

[2] P. Peodjijo, Hubungan Antara Gaya Kepemimpinan Kepala Sekolah dan Motivasi Kerja Guru dengan Kinerja Guru SMU di Wilayah Bogor, Tesis Program Pascasarjana Universitas Pakuan, Non Publisher, 2002

[3] Anonim, Undang-Undang Nomor 14 Tahun 2005, Tentang Guru dan Dosen, Jakarta: Visimedia, 2007.

[4] J. M. George and G. R. Jones, Organizational Behavior, third edition, New Jersey: Upper Saddle River, 2002.

[5] D. L. Nelson, and J. C. Quick, Organizational Behavior: Foundations, Realities, and Challenges, Thomson/South-Western, 2006.

[6] J. L. Gibson, H. Donelly, Jr. Jhon, M. Ivancevich, Manajemen, Jakarta: Erlangga, 2006

[7] M. S. P. Hasibuan, Manajemen Sumber Daya Manusia, Jakarta: Bumi Aksara, 2001

[8] L. S. McShane, and M.A.V Glinow, Organizational Behavior, New York: McGraw-Hill, 2010.

[9] S. P. Robbins and M. Coulter, Management, London: Pearson Education, 2014

[10] T. S Bateman, and S. A. Snell, Manajemen Kepemimpinan dan Kolaborasi dalam Dunia yang Kompetitif, Jakarta: Salemba Empat, 2009

[11] R. W. Terry, Kepemimpinan Autentik, Batam Centre: Interaksara, 2002

[12] G. Yukl, Leadership in Organization Fifth Edition, New York Prentice Hall, Inc, 2011

[13] S. Danim, and Suparno, Manajemen dan Kepemimpinan Transformasional Kekepalasekolahan, Jakarta: Rineka Cipta, 2008 